\title{
Motivations to Become Teachers in Canada: Perceptions from Internationally Educated Teachers
}

\author{
Kangxian Zhao \\ University of Toronto, Canada
}

\begin{abstract}
Drawing from a broader study of internationally educated teachers (IETs) in Canada, this paper focuses on IETs' motivations to take up or return teaching profession in Canada. Eleven motivators were identified among 20 IETs. Research findings indicate that IETs took up or returned to teaching profession for a variety of reasons, in addition to the typical intrinsic, extrinsic, and altruistic motivating factors.
\end{abstract}

\section{Introduction}

Educational researchers and policy makers have recognized "the importance of having motivated teachers to ensure the high quality of schools" [1]. With global migration, like many other internationally educated professionals, internationally educated teachers (IETs) ${ }^{1}$ have been increasingly present in different countries. Studies of IETs have gradually become pertinent in the field of education. Issues related to IETs have raised great interests with many researchers and educators [2, 3, and 4]. However, very few studies investigated IETs' motivations for teaching in the hosting countries. The present study draws from a broader research which explored IETs' transition from initial teacher education programs to the workplace in Canada. This paper focuses on IETs' motivations to take up or return to teaching profession.

\section{Literature Review}

The research literature of teacher motivation reveals that researchers and educators usually categorize the motivations for teaching into intrinsic, extrinsic, and altruistic motives. Numerous studies have investigated pre-service teachers' motives to become teachers [1, 5, and 6]. Roness and Smith [1] found that the students at teacher education programs in Norway were intrinsically motivated to choose teaching as their profession and their motivations for teaching were stable over a period of one-year course

\footnotetext{
${ }^{1}$ In this paper, I use internationally educated teachers to refer to immigrant teachers who taught in other countries before, immigrants who became teachers in the hosting countries, or immigrant teachers/teacher candidates who worked, studied, or lived in other countries before.
}

study. Younger et al. [5] identified a number of teacher motivations among 36 secondary teachers: the intrinsic value of the subject matter, positive schooling experience, career change, and passion. Recently, Richardson and Watt [7] and Watt and Richardson [8] proposed a Factors Influencing Teaching Choice (FIT-Choice) framework to understand the motivation for choosing a teaching career. The FIT-Choice model contains socialization influence (social dissuasion, prior teaching and learning experiences, social influences), task perceptions (task demand and task return), self perceptions (teaching abilities), values (intrinsic, personal utility, and social utility values) and fallback career. Richardson and Watt [7] found that the highest rated motivation for teaching among 1653 Australian preservice teachers were their perceived teaching abilities, the intrinsic value of teaching, and their desire to make a social contribution, shape the future, and work with children/adolescents. Most recently, Klassen et al. [9] compared the teacher motivation of Canadian to Oman preservice teachers from a sociocultural perspective. They found that Canadian preservice teachers made more selfreferences, and expressed higher levels of individualfocused motivation and intrinsic career value as motivators. Oman teachers considered teaching as a fallback career and higher level of sociocultural influences on their career choice.

\section{Research Methods}

In the broader research project from which this paper draws, research data were mainly collected from semi-structured interviews, short questionnaires, and research participants' writing, informal conversations through online chatting with participants, emails, and field notes. I met these participants in person, or interviewed them on phone or through online conference software Skype. Each participant was asked to fill out four short questionnaires after the first interview. Only one participant has not returned the questionnaire document. Follow-up interviews were conducted three to seven months after the first interview. Some participants were followed-up by emails. In addition, to have in-depth exploration, I interviewed four focal participants three more times over a period of three months. As I speak two dialects (Cantonese and Mandarin) of Chinese language fluently, all participants of Chinese ethnic chose to speak 
Mandarin during the interviews. Interviews with 19 participants were recorded with a digital recorder. One participant did not want the interviews recorded. The research data I present in this paper were mainly from interviews and participants' writing. Data originally in Chinese were translated into English.

Twenty IETs (14 women and 6 men) participated in the study. The majority (18 IETs) of the group were educated and certified in the province of Ontario. One of them found a permanent teaching position in another province Alberta and moved there after the first interview. Another IET found a oneyear contract in the province of Manitoba and moved there after the fourth interview. In addition, one IET was certified in New Brunswick, and another was certified and teaching in Quebec. These IETs immigrated to Canada from 12 different countries and areas-Albania, Guatemala, India, Korea, Mainland China, Malaysia, Pakistan, Singapore, Taiwan, the Philippines, Turkmenistan and Trinidad. Their age ranges from 20s to 50s. Before coming to Canada, a number of IETs have already been experienced teachers for years, some IETs just completed undergraduate or graduate studies, and some were still high school students. Three visible minority IETs speak English as their mother tongue. The other seventeen participants speak English as their second or other language, including two invisible minority IETs.

\section{Research Findings}

A number of themes were identified as IETs' main motivations to teach in Canada: teaching background, motherhood, second language speaker identity, passion for teaching, helping, impact of family members or role models, job feature and job benefits, employment, change career, personality, and subject matter.

\subsection{Teaching background}

Sixteen of the 20 IETs had teaching experiences before they entered Canadian initial teacher education programs. They chose to return to teaching profession because of their teaching background"Because I was a teacher." Some of these teachers (e.g., Charles, Bill, and Kent) taught in colleges and universities when they were studying in graduate schools in Canada or the United States. Some (e.g., Jack, Jane, and Shyla) have been university professors in their countries of origin for a number of years. Others taught in K-12 schools or have worked as tutors. Some IETs (e.g., Donieta and Smith) also taught in private schools in Canada before they entered the initial teacher education programs. Some IETs (e.g., Bella, Jack, and Nalita) had working or teaching experiences in Canadian public schools as volunteers. These teachers wanted to continue their teaching career in Canada.

\subsection{Motherhood}

Three IETs (Bella, Jasmine and Rose) mentioned that they chose to take up or return to teaching in Canada after they have their own children.

I wanted to know more about the educational system in Canada after I have my daughter. (Bella)

I have four children. I want to learn education. So I can help my own kids. (Jasmine)

Ten years ago, I came to Canada as an international student. I studied Business Administration and Information Technology in university. I worked at a manager assistant position for a year. I got married. I have my own children. I started to pay attention the education in Canada. Then one of my friends said, why don't you study for a teaching certificate, so you can become a teacher. (Rose)

\subsection{Second language speaker identity}

IET Cecilia also indicated that she chose to become a teacher because English is her second language. "If my English were better, I would have chosen to study business management." She explained that she had no problem speaking English but writing in English gave her headache. Math is her strength. She is happy teaching math as she doesn't have to write in English much.

\subsection{Passion for teaching}

“Teaching is meaningful.” (Kent)

"Teaching is rewarding." (Soop)

"I am passionate about teaching. That's the reason I did my B.Ed.” (Nalita)

All of the IETs in this study indicated that they loved to teach and they enjoyed working with kids/students. During the interviews, I heard IETs voice their passion for teaching again and again. For example, Sunyi immigrated to Canada with her parents nine years ago when she was still a high school student. She had tutoring experiences in high school and university.

I had passion for teaching. I had experience being a tutor. I did peer tutoring in high school. Later I also did tutoring in university. I love teaching. I enjoy teaching. So I decided to become a teacher. 


\subsection{Helping}

For many IETs, teaching is one way of helping other people. They want to help students through their teaching. For example, Soop, a Singaporean Chinese, taught English and home economics at high school in Singapore over 25 years ago. Soop came to Canada as an international student. Soop has worked in a courier company in New Brunswick for 15 years. A few years ago, Soop decided to return to teaching.

My daughter is getting older. I have more time... I would like to teach in Africa or Southeast Asia after my daughter goes to university...I like to help people. I want to contribute to the society. Teaching is one way of helping.

Bella volunteered at public schools and a charitable organization that helps youth in lowincome communities for three years before she went to study in the teacher education program.

I want to help these kids. I was so happy that some of the students I tutored could go to university. I felt so successful when they told me the good news.

\subsection{Impact of family members and role model}

In this study, two IETs (Jasmine and Bella) indicated that they chose to become a teacher partly because they were familiar with the teaching profession because some of their family members were teachers. Bella came to Canada eight years ago to join her husband after she finished her studies at a law school in China. Then she studied in the Electronic Engineering program in a Canadian university. Bella related her decision to become a teacher partly because some of her relatives were teacher and she had good learning experiences with some of the teachers who became her role model.

I always wanted to be a teacher. In my family, two of my uncles and two of my aunts were teachers. Two of them taught in elementary schools and the other two taught in secondary schools. When I was in high school, I had two very good teachers. One is a Math teacher, the other is an English teacher. I was very shy. I didn't want to talk to anybody. My English teacher encouraged me. I gained a lot of confidence in her class. She is my first inclusive teacher. My math teacher has a very good sense of humor. She was very good. I wanted to be a teacher like her.

Seyit is an IET from Turkmenistan. He had taught Math in university for 14 years. He immigrated to Canada with his wife, three children, and his mother eight years ago. He went directly to a Canadian university to study an honour degree in Math and Physics. He returned to teaching not only because of his teaching background, but also the impact of his family.

I went to teacher education program because I was a teacher. Teaching was the only job I did. Actually I have tried others. For example, I was eligible to apply for the medical doctor program at the University of Toronto because of my high average and I've taken all the life science courses, biology, chemistry, physics, with very high average, another program I was thinking was Radiation Oncology. I talked with my family. I have three children. I have my wife. My mother is with me. So I have people to talk with. I talked with them. They said, oh, no, medical stuff is just not for you. Teaching.

\subsection{Job feature and benefits}

Some IETs indicated that part of the reasons that they chose to teach in Canada is that teaching is a decent profession with good bonus and long vacation. They want to have more time to take care of their family. For example, Bill taught Computer Science in a college when he was studying for his Master's degree in the U.S. His original plan was to find a programmer position in Canada.

One of my friends said, you taught before, why don't you get a teaching license? Teaching in Canada is different from that in the U.S., because teaching in the U.S. is not so stable. Teaching profession here is more stable. So I thought, great, then I will try to get a teaching license.

Bella wanted to teach because she was familiar with teaching profession, she wanted to help students, and she also wanted to have more time to take care of her family.

Teaching would be good for me. My husband is a lawyer, so he's busy most of the time. I would have more time to take care of my daughter if I work as a teacher. I can take care of her in the summer, so she doesn't have to go to summer camp.

Jane decided to become a teacher in Canada because of her teaching background, her personalities, and the job benefits.

Because I was a teacher in China. I think teaching is an appropriate profession for me. In addition, I think the job benefits of teaching are quite good. I have done a bit research before I applied for teacher education. I had some general idea about the salary. I think teaching is a decent career. 


\subsection{Employment}

For most IETs, the ultimate goal of going back to university, getting teaching certificates is to find permanent teaching positions in Canadian public schools. Some IETs (e.g., Charles, Jenny, Lara, and Seyit) indicated that employment was one of their motives. For example, Jenny immigrated from Taiwan eight years ago. She went through English language learning, graduate studies in Second Language Education, college diploma in Early Childhood Education, and then she became a certified teacher in Ontario. Her main motivation was to improve her employment status by finding a teaching position in Canada

My Master's degree could not get me a teaching job. That degree might be more useful if I go back to Taiwan. But in Canada, that degree won't be useful unless I have obtained a teaching position. If I want to stay in Canada (to teach), I have to get a (teaching) certificate.

Many IETs had worked in other fields before they studied in the Canadian initial teacher education program. For example, Lara, Jane, and Shyla all had experiences working at customer service positions. Shyla had been a university professor for over fifteen years in India.

After I moved here, it was difficult to find a job in my profession, so I just worked, like, minimal wages in a store...I was a Ph.D. but I was not allowed to teach in schools without having a Bachelor of Education. So I went for that.

For her first four years in Canada, IET Lara worked at worked at a toy store, a call centre, then she worked in a greenhouse, and then another call centre.

I was constantly frustrated at the kind of jobs

I was getting in Canada

Going through Canadian teacher education programs is one of the ways for IETs to return to teaching in public schools, though they had teaching qualifications from other countries and previous teaching experiences.

\subsection{Change career}

As mentioned previously, a number of experienced IETs worked at non-teaching positions after immigrating to Canada. They went back to university for teacher education programs to be (re)certified, so they could switch their career back to teaching profession. In addition, two IETs (Kent and Charles) were working at non-teaching professions. They chose to study in teacher education program so they could work in teaching profession. Kent had a background in chemical engineering and worked as an engineer after he obtained his doctoral degree. However, he did not like what he did as an engineer and decided to change career. He returned to teaching to do something more meaningful according to his beliefs.

Charles immigrated to Canada with his parents long time ago and went back to Taiwan for his education. Later he worked as a TA when he was studying for his $\mathrm{Ph}$. D in the United States. After graduation, Charles worked at non-teaching positions in Taiwan for 13 years. Two years ago, Charles decided to return to Canada and pursue a teaching career. His teachable subjects are Math and Physics.

I have been changing career. I studied Physics in Taiwan. Later, I studied Physics in my Master's. Then I did semi-conduct... I went to the U.S.... Then I went back to Taiwan...Now I found a job teaching co-op. I'm not going to teach Math or Physics.

For Charles, becoming a teacher was not only to change profession; it was also to do something less demanding.

I have been working in different countries in the past couple decades. Also, to me, becoming a high school teacher means moving from high pressure job into low pressure.

\subsection{Personality}

A number of IETs (e.g., Bella, Cecilia, Jane, and Kent) related their choice of entering teaching profession to their personalities. For example, Bella studied in an engineering program after immigration, but she realized that she preferred working with human beings instead of machines or computers.

If I have to work with machines or computers every day, I would be bored to death. I think my personalities are good for teaching.

\subsection{Subject matter}

Bella and Cecilia chose to become teachers because of subject matter. Bella realized that she did not want to work with machines or computers. She preferred to interact with other people through teaching. Cecilia was studying Actuarial Science in university. In the third year, she decided to transfer to study a specialized program so become a teacher.

When I finished my second year, I changed my mind. Because in the first year, there were no courses of Actuarial Science, only general courses. In the second year, I took some courses in Actuarial. Then I realized that that wasn't what I wanted to do, because it's all about memorizing the formulas. That wasn't my interest. So I transfer to Specialist in Mathematics. 


\section{Discussion}

IETs' motivations of becoming teachers in Canada consist of intrinsic and extrinsic factors. For many immigrants, leaving their homeland also means leaving their established career behind. They need to develop their career in a new setting. Teaching in Canada is a decent profession with good bonus and long vacation. Therefore, improving employment status, job features of teaching and benefits were some IETs' motivations for teaching.

In Hwang, Baek and Konstantino’s study [6], the immigrant Hispanic/Latinos teachers' motivation to choose teaching profession was intrinsic reason and the influences of family or teachers. In the present study, for IETs who were teachers before, the most frequent motivation is their teaching background. In Ng's [10] study, all of the five IETs were in different professions in their homeland or in Canada before they became certified teachers in Canada. They changed to teaching profession because they had working experience with children or in educational environment after immigration. In the present study, for IETs who were not teachers before, being a mother has great impact on their career choice.

Previous research literature showed that many IETs experienced difficulties during their (re)credentialing, seeking employment, and/or teaching because of their second language speaker identity [10, 11]. Most of the IETs in this study speak English as their second or other language. It's surprising to hear that an IET wants to teach because English is her second language.

Richardson and Watt [7, 8] categorized the influence of previous teaching and learning experiences and the impact of role models as socialization influences. Viewing from the FIT Choice framework, some of IETs chose to become teachers because of socialization influences - the impact of their family members or role models.

In addition, through the lens of sociocultural theory, particularly the perspective of identity, IETs' chose to teach because of who they are (e.g., immigrants, teachers, mothers, second language speaker) and whom they want to be (teachers in Canada) through participation in the community of practice.

\section{Conclusion}

By exploring 20 IETs' motivations to become teachers, the current study provided an important perspective in understanding IETs transitional experience from initial teacher education programs to the workplace.

Research data in the current study indicated that IETs took up or returned to teaching in Canada because of a combination of intrinsic, extrinsic, altruistic factors, socialization influence, and other motives. These IETs all seemed to be very motivated to become certified teachers in the new setting.

\section{References}

[1] D. Roness, and K. Smith, "Stability of motivation during teacher education", Journal of Education for Teaching, Routledge, London, 2010, pp. 169-185.

[2] J. Myles, L. Cheng, and H. Wang, "Teaching in elementary school: Perceptions of foreign-trained teacher candidates on their teaching practicum", Teaching and Teacher Education, Elsevier, London, 2006, pp.233-245.

[3] H. Mawhinney, and F. Xu, "Reconstructing the professional identity of foreign-trained teachers in Ontario schools”, TESOL Quarterly, 1997, pp. 632-639.

[4] S. Walsh, and S. Brigham, Internationally educated teachers and teacher education programs in Canada: Current initiatives, Atlantic Metropolis, Halifax, 2007.

[5] M. Younger, S. Brindley, D. Pedder, and H. Hagger, "Starting points: student teachers' reasons for becoming teachers and their preconceptions of what this will mean", European Journal of Teacher Education, Carfax, London, 2004, pp. 245-264.

[6] Y. Hwang, E. O. Baek, and Konstantinos, V., "Immigrant Hispanic/Latinos teachers' perception of education", Paper presented at the meeting of the American Educational Research Association, Montreal, Canada, 2005.

[7] P. Richardson, and H. Watt. Who chooses teaching and why? Profiling characteristics and motivation across three Australian universities. Asia-Pacific Journal of Education, 34, Taylor \& Francis, Singapore, 2006, pp. 27-56.

[8] H. Watt, and P. Richardson. Motivational factors influencing teaching as a career choice. The Journal of Experiential Education, 75, Association of Experiential Education, Boulder, CO, 2007, 167-202.

[9] R.M. Klassen, S. Al-Dhfri, W. Hannok, and S. Betts (2010). Investigating pre-service teacher motivation across cultures using the Teachers Ten Statements Test. Teaching and Teacher Education, 27, Elsevier, Amsterdam, 2010, pp. 579-588.

[10] O. Ng, "Narrative beyond teaching: Inquiry into the shifting identity, cultural and professional practice of five visible minority immigrant teachers in a diverse lifespace", unpublished doctoral dissertation, University of Toronto.

[11] N. Amin, Negotiating nativism: Minority immigrant women ESL teachers and the native speaker construct. Unpublished doctoral dissertation, University of Toronto, Toronto, Ontario, Canada, 2000. 